\title{
A New Method for the Authentication of Australian Honey ${ }^{+}$
}

\author{
Sadia A. Chowdhury 1,2,*, Shalona R. Anuj 1, James F. Carter 1, Natasha L. Hungerford 2, \\ Dennis Webber ${ }^{2}$, Yasmina Sultanbawa ${ }^{2}$ and Mary T. Fletcher ${ }^{2}$ \\ 1 Forensic and Scientific Services, Queensland Health, 39 Kessels Road, Coopers Plains, QLD 4108, Australia; \\ shalona.anuj@health.qld.gov.au (S.R.A.); jim.carter@health.qld.gov.au (J.F.C.) \\ 2 Queensland Alliance for Agriculture and Food Innovation (QAAFI), The University of Queensland, \\ 39 Kessels Road, Coopers Plains, QLD 4108, Australia; n.hungerford@uq.edu.au (N.L.H.); \\ Dennis.Webber@daf.qld.gov.au (D.W.); y.sultanbawa@uq.edu.au (Y.S.); mary.fletcher@uq.edu.au (M.T.F.) \\ * Correspondence: sadia.chowdhury@health.qld.gov.au \\ + Presented at the third International Tropical Agriculture Conference (TROPAG 2019), Brisbane, Australia, \\ 11-13 November 2019.
}

Published: 3 March 2020

\begin{abstract}
The honey bee industry in Australia is small but has a big impact on both producers and consumers. Alarmingly, it has been recently reported that an international laboratory, specializing in honey authentication, found that almost half of the 28 blended and imported honey samples selected from Australian supermarket shelves were "adulterated". The Official method of honey analysis (AOAC 998.12) is based on the stable-isotope ratio mass spectrometry analysis of $\delta^{13} \mathrm{C}$ value of honey versus $\delta^{13} \mathrm{C}$ of honey protein to detect the addition of $\mathrm{C}_{4}$ plant derived sugars, such as cane sugar or high fructose corn syrup. This method is used as the primary $\mathrm{C}_{4}$ sugar adulteration test around the world, but honey derived from some Australian plants, particularly Manuka (Leptospermum species), fails this process. Our research aims to examine the characteristics of Australian honey and develop a test that is fit for purpose, particularly where honeys derived from Leptospermum species are concerned. We have focused on the isotopic values of "proteins" precipitated using the standard AOAC method and "proteins" precipitated after incorporation of a further modification step which removes insoluble material (including pollen) from the honey before precipitation. Our modified method includes the analysis of different isotopes of the precipitated protein, sugar profiles and Manuka markers. A key advantage of the proposed modification is that it does not preclude the detection of residual sugar feeding of bees or extension of honey with $\mathrm{C}_{4}$ sugar. The proposed modification to the AOAC test will reduce false identification of $\mathrm{C}_{4}$ sugars and improve the overall reliability of Australian honey authentication.
\end{abstract}

Keywords: honey authenticity; stable isotope ratio; $\mathrm{C}_{4}$ sugar; adulteration; authentication

Author Contributions: All authors have read and agreed to the published version of the manuscript. Methodology, S.A.C., J.F.C., S.R.A.; data analysis, S.A.C.; Writing-original draft preparation, S.A.C.; writingreview and editing, S.A.C., J.F.C., N.L.H., M.T.F.; funding acquisition, S.A.C.; supervision, M.T.F, J.F.C.;

Funding: This research was funded by Queensland Health Grant RSS 18-022.

Conflicts of Interest: The authors declare no conflict of interest.

(c) 2020 by the authors. Licensee MDPI, Basel, Switzerland. This article is an open access article distributed under the terms and conditions of the Creative Commons Attribution (CC BY) license (http://creativecommons.org/licenses/by/4.0/). 